\title{
Ecological conservation, remediation and construction for building an ecological civilization in China: concepts for ecological activity
}

\author{
Guofang SHEN (ه) \\ Chinese Academy of Engineering and Beijing Forestry University, Beijing 100091, China
}

\begin{abstract}
This paper explains and discusses the concepts of ecological conservation and construction in China in three parts. The first part provides a brief description of the historical background of ecological activities in China and their major achievements in the past. The second part is a comprehensive review of various types of ecological control activity aimed at the improvement of natural and artificially established ecosystems at the landscape, regional (watershed) and higher levels. The scope of and differences between some ecological terms used in China such as ecological protection, conservation, remediation (rehabilitation), restoration as well as the reestablishment of new ecosystems are elaborated. The review suggests that the term "ecological conservation and construction" should be used to embrace all types of ecological control activity in China. Finally, five guidelines are proposed for promoting the implementation of ecological conservation and construction in China based on the two important governmental documents related to the development of ecological civilization in China.
\end{abstract}

\section{Introduction}

China, a large ancient country with a vast territory covering highly diverse natural conditions, has a long history of exploration and exploitation of all its natural ecosystems. Extensive and intensive uses of natural resources have greatly changed the land and water systems, creating a patchwork of ecosystems with only a small part (about $10 \%$ ) of its natural ecosystems remaining untouched and in an ecologically pristine condition.

Since the founding of the People's Republic of China in 1949 , and especially since the start of the economic reform in 1978, large scale activities for conserving, remediating,

Received September 7, 2017; accepted November 21, 2017

Correspondence: shengf@cae.cn rearranging and reconstructing the natural ecosystems have been initiated by the government and implemented by the people in order to reverse the long history of deterioration and destruction of natural ecosystems.

The first symbolic action was the initiation of a longterm ecological project, the Three-North Shelter Forest System Project, also known domestically and internationally as the Green Great Wall Project ${ }^{[1,2]}$. This initiative has been followed by large scale afforestation projects in various regions of China, such as in the upper reaches of the Changjian (Yangtze) River, in the upper reaches of the Pearl River, on the Loess Plateau in the middle reaches of the Yellow River, in the Taihang Mountains region in Hebei, Shanxi and Henan Provinces. A breakthrough happened toward the end of last century (1998-2000) with two impressive ecological projects, Natural Forests Protection and Returning Farmland to Forests (internationally known as the Grain for Green program) that were accepted and initiated by the Central Government. These projects have substantially improved the ecological conditions throughout the entire country.

During the first decade of the current century, projects for combating desertification, grassland conservation and amelioration, plus wetland conservation redlining, and other initiatives such as eco-cities and forest-cities in urban areas, were advanced one by one. All received substantial budget support and capital investment. These efforts have led to a measurable improvement of the national ecological condition. There have been 407 national nature reserves established since 1956. Forest coverage has increased from $12 \%$ in the 1970 s to over $21 \%$ at present. The area of soil erosion has been reduced by $61000 \mathrm{~km}^{2}$ in the past 15 years. Desertification has been reversed with an annual reduction in desertified land area of $2491 \mathrm{~km}^{2}$ between 2006 and 2011, and an additional $232 \mathrm{~km}^{2}$ of wetland area, representing about $44 \%$ of the entire wetland area in China, has been conserved in various types of protected areas. All these achievements have been surveyed, reported and acknowledged publicly, both domestically and 
internationally. China's efforts have been praised by many experts, NGOs, and by some UN organizations based on their own observations that the progress and success in ecological conservation, restoration and construction is unprecedented for a developing country ${ }^{[3]}$. This is particularly so when considering China's large and diverse area and biodiversity, range of types, complexity and diversity of the activities and measures, and finally the huge investment of hundreds of billions of CNY.

The year 2012 marked the advancement of ecological efforts in China to a new level ${ }^{[4,5]}$. The concept of building an ecological civilization was proposed and raised by the CPC and Central Government to a new level. It has been set as a long-term goal of national construction in line with and linked to the other key fields of national economical, social, political and cultural construction. So, the building of ecological civilization in China is the task of not only the relevant ministries and government agencies but also the nation and the society as a whole for the well-being of the entire population. Ecological conservation, remediation and construction together form one of the most important pillars to support the target of building an ecological civilization in China.

\section{Scope and types of ecological activity in China}

The great diversity of the natural ecosystems in China, together with the long and complex history of their exploitation and degradation, has led to the great complexity of the current circumstances, and the need for highly diverse measures to restore and sustain these ecosystems. From an academic perspective, the measures taken can be considered within the scope of conservation and restoration ecology. However, for many reasons China's undertakings go far beyond the target of restoration itself, and many ecological activities are oriented not only to the restoration of ecosystems to their former state, but also to the formation of new types of ecosystem, considering the substantial changes of hydrological, soil and other conditions related to their degradation.

Ecological activities in China are oriented not only toward conservation, remediation and restoration of natural ecosystems, but also toward the ecological improvement of human-constructed ecosystems (i.e., artificially-established ecosystems), such as farmland, urban areas and various sites of infrastructure development. Furthermore, China's ecological improvement initiatives are undertaken at the levels of landscape (a certain combination of several natural ecosystems) and of region (e.g., watershed and coastal zone units), which demand that more strategic and comprehensive measures are taken. Thus, we can classify ecological activities in China into categories and types according to their specified objectives and actual practices.

Firstly, in situations where natural ecosystems are the main focus of ecological activity, there are four categories of activities according to the level of degradation of the ecosystems, as detailed in Table 1.

Secondly, as shown in Table 2, the ecological activities in China should meet the needs of ecological improvement in the artificially-established ecosystems.

The terminology in Tables 1 and 2 shows that these days in China remediation is a favored and more frequently used concept than restoration ${ }^{[6]}$. This might be because in most cases the degraded or damaged ecosystems cannot actually be fully restored to their former condition. Rather, they are remediated (rehabilitated) or reconstructed in the form of new ecosystems ${ }^{[7]}$. However, there may be important implications for the value of their ecological services and biodiversity, for example in some artificial forests and grasslands.

At the higher ecosystem levels, such as landscapes, watersheds, regions and even the global biosphere, the ecological protection activities should be more strategic and comprehensive. A summary of ecological activity at different levels of ecosystems is shown in Table 3.

Many of China's ecological engineering projects are designed at the watershed and/or regional levels. For instance, the national projects for soil and water conservation, combating desertification and conversion of farmland to forests and grasslands are planned at the national level but implemented in each geographical region in accordance with its specific natural and socioeconomic conditions. These projects were formulated and advanced with strategic objectives through the consideration of the local requirements, feasibility and likely impact. They have

Table 1 Categories and types of ecological activity for natural ecosystems

\begin{tabular}{ll}
\hline Level of degradation & Type of ecological activity for natural ecosystems (forest, grassland, desert, wetland, water and ocean) \\
\hline $\begin{array}{l}\text { Primitive or nearly primitive natural ecosystems } \\
\text { (no degradation) }\end{array}$ & $\begin{array}{l}\text { Preservation under protection in the different types of protected area, with a strong emphasis on biodiversity } \\
\text { preservation }\end{array}$ \\
Slightly degraded & $\begin{array}{l}\text { Conservation of natural ecosystems with limited supportive measures, such as human-assisted regeneration } \\
\text { and maintenance }\end{array}$ \\
Severely degraded and damaged & $\begin{array}{l}\text { Remediation (rehabilitation) of natural ecosystems with more radical measures, including introduction or } \\
\text { change of the dominant species, and change of the composition and structure of the vegetation } \\
\text { (reconstruction), and amelioration of hydrological and soil conditions }\end{array}$
\end{tabular}

Totally destroyed 
Table 2 Categories and types of ecological activity for artificially-established ecosystems

\begin{tabular}{ll}
\hline Categories of ecosystem & Type of ecological activity \\
\hline Fields (cultivated farmland) and pastures & $\begin{array}{l}\text { Soil remediation and amelioration, establishment of shelterbelt systems, agroforestry practices, and } \\
\text { ecological (circulative) agriculture }\end{array}$ \\
Cities and towns (urban areas) & $\begin{array}{l}\text { Tree planting in urban and suburban areas, and other } \\
\text { urban forestry practices, landscape architecture (gardening), indoor courtyard greening and vertical } \\
\text { greening (including rooftops), river and lake restoration, coastal ecosystem protection and restoration, and } \\
\text { artificial ecological development in artificially-reclaimed coastlands }\end{array}$ \\
& $\begin{array}{l}\text { Abandoned and subsided mine remediation, industrial brownfield remediation/restoration, greening of } \\
\text { active industrial sites, remediation of sites damaged by road, rail, water and power supply infrastructure } \\
\text { construction, water reservoir shoreline rehabilitation, and green way system establishment }\end{array}$ \\
\hline
\end{tabular}

Table 3 Categories and types of ecological activity for ecosystems at higher levels (landscapes, watersheds, regions and global biosphere)

\begin{tabular}{ll}
\hline Level and scale of ecosystem & Type of ecological activity \\
\hline Landscape & $\begin{array}{l}\text { Land use planning, regulation of the size and types of ecosystem or components to be harmoniously } \\
\text { compatible within a landscape }\end{array}$ \\
Medium and small watersheds & $\begin{array}{l}\text { Conservation, remediation and, sometimes, establishment of new ecosystems (e.g., afforestation and } \\
\text { grassland establishment) on the basis of rational land use patterns }\end{array}$ \\
$\begin{array}{l}\text { Region (major river basin or mountain area, ocean or } \\
\text { coastal zone) }\end{array}$ & $\begin{array}{l}\text { Land use regulation on a broad scale, with ecological improvements for each ecosystem component an } \\
\text { consideration of ecosystem linkages, synergies and other impacts, policies for institutional and financia } \\
\text { support }\end{array}$ \\
Global biosphere & $\begin{array}{l}\text { Emphasis on biodiversity preservation, especially for species and ecosystems of global or regional } \\
\text { concern, plus comprehensive measures for expansion of biological carbon sinks, with concurrent } \\
\text { reduction of carbon and other pollutant emissions }\end{array}$ \\
\end{tabular}

adopted comprehensive measures, including activities in agronomy, forestry, livestock husbandry and hydrological engineering, as well as other socioeconomic aspects.

The ecological activities in China given in Tables 1-3 are all large scale in terms of the physical or geographical area and the size of investment, and are all comprehensive in nature with combined implementation of various categories and types of activity. The terms, ecological conservation or ecological restoration, cannot adequately encompass all of the diverse activities. So, in China we have selected the term ecological construction to embrace all categories and types of ecological activity. The concept of construction is very popular in China. As the opposite of destruction, construction it is used not only in physical contexts, such as house construction and road construction, but also in social contexts, such as ideological construction and manpower resource construction. However, some might argue that construction could mean anything from doing almost nothing to achieving a completely new establishment ${ }^{[8]}$.

In addition, the word, construction, can have negative overtones (i.e., implying heavy emphasis on massive human intervention) that have come from setbacks in some ecological projects, especially where the laws of nature and their capacity for self-repairing and recovery have been ignored. The lessons learnt from these setbacks have led to an increased use of ecological protection (conservation) and ecological remediation in recent government documents and academic literature. Consequently, it is more flexible and comprehensive to use the combined term, ecological conservation and construction, to reflect the reality of the diversity and breath of ecological control activities in China. This suggestion has been adopted and used in the newest government documents regarding ecological civilization in China ${ }^{[9]}$.

\section{Guidelines for the future}

The new national leadership headed by President $\mathrm{Xi}$ Jinping is keen to resolve the ecological-environmental problems of the country and is very enthusiastic in the endeavor of building an ecological civilization in China. Under its framework of ecological policies, the long-term effort of ecological conservation and construction will be sustained or even enlarged in scale during the next few decades, leading to an extensive and substantial improvement of ecological conditions in China. This will be a great contribution of China to the world because it is unprecedented for humankind for such an achievement to occur in a large developing country with a vast, deteriorated territory, and with a long history of ecodegradation due to overpopulation and agricultural and industrial development.

The guiding thought and concepts of the institutional reform for building an ecological civilization have been clearly stated in two important government documents, Views on speeding up the promotion of Building the Ecological Civilization and The General Scheme of the Institutional Reform for Ecological Civilization, released 
in May and September 2015 by the Central Committee of the CPC and the State Council of the PRC ${ }^{[10,11]}$.

In accordance with these documents, and the realities of the situation in China, several guidelines for further actions in ecological conservation and construction are proposed.

(1) China's ecological conservation and construction activities should be problem-focused and undertaken to ensure ecological safety regionally and nationally, and provide the foundation for harmony between nature and people.

(2) Ecological conservation and construction activities should be undertaken with priorities of protection (conservation) first and natural recovery as the main path, along with the integrated use of compatible artificial measures, as required.

(3) Ecological conservation and construction activities should provide substantial increases in the natural capital, and generally promote the comprehensive functioning of all four ecosystem services: provisional, regulatory, supportive and cultural.

(4) Experiences, arising from both the achievements and setbacks of past activities, should be carefully summarized and taken into account for improving future actions in ecological conservation and construction.

(5) Considering nature as a common body of its components: mountains and rivers, forests and farmlands/pastures, wetlands and deserts, and oceans, the ecological conservation and construction activities should be undertaken in a systematical way to provide comprehensive control and improvement to the national and regional ecological conditions to provide sustainable benefits to the people and the ecosystems on which they depend, and therefore, for ecological security locally, nationally and globally.

Compliance with ethics guidelines Guofang Shen declares that he has no conflict of interest or financial conflict to disclose.

This article is a review and does not contain any studies with human or animal subjects performed by the author.

\section{References}

1. Liu J. Chinese national ecological environment construction planning. Beijing: Chinese Industrial and Commercial Federation Press, 1999 (in Chinese)

2. Li S D. World's important ecological engineering. Beijing: Science Press, 2008 (in Chinese)

3. Zhu G Y, Shen G F et al. The comprehensive report of the studies on macro-environment strategy in China. In: Chinese Academy of Engineering and Ministry of Environment Protection eds. Studies on the macro-environment strategy in China: Volume 1. Beijing: China Environmental Science Press, 2011 (in Chinese)

4. Hu J T. Advance unswervingly along the path of socialism with Chinese characteristics strive to build a well-off society in an allround way. The Eighteenth National Congress of the Communist Party of China, 2012 (in Chinese)

5. She G F, Li S D, Wu B, Zhang S G. Studies on some strategic issues of the ecological conservation and construction in China. China Engineering Science, 2015, 17(8): 23-29 (in Chinese)

6. Zhang X S. Some considerations on ecological restoration/recovery and its content and development path way. In: Li W H eds. China's contemporary ecological researches: ecosystem recovery. Beijing: Science Press 2013 (in Chinese)

7. Shen G F. China's ecological Construction engineering: concepts, scopes and achievements. Forestry Economy, 2007, (11): 3-5 (in Chinese)

8. Shen G F. Discussion about the designation and content of ecological conservation and construction. Acta Ecologica Sinica, 2014, 7(34): 1891-1895 (in Chinese)

9. Jia Z B. About the ecological civilization. 2nd ed. Beijing: Chinese Forestry Publishing House, 2015 (in Chinese)

10. Central Committee of the Communist Party of China and State Council of the Peoples Republic of China. Views on speeding up the promotion of building the ecological civilization. People's Daily, 2015, April 25 (in Chinese)

11. Central Committee of the Communist Party of China and State Council of the Peoples Republic of China. The General Scheme of the institutional, reform for ecological civilization. People's Daily, 2015, September 21 (in Chinese) 